asphyxia at once recurred. The reinsertion of the tube immediately relieved the condition.

4. Vomited Matter.-Food particles are often made responsible for some cases of obstructed respiration, especially when the respiratory difficulty follows movements which have been considered to indicate sickness. Such movements are not, however, due to sickness in many instances, but to the obstruction in the respiratory passage.

5. The Obstruction may be due to Two or More of the above Causes combined.-This is probably the true explanation. For example, tenacious secretion in the larynx or trachea, accompanied by spasm or cedema of the chords, would effectually block the air passages for some time. These different causes would enter into the condition in varying degrees in the different cases.

\section{a Case of Fatal arrest of Respiration.}

The report of the following fatal case of chloroform anæsthesia, which has not, to my knowledge, been published hitherto, seems to suggest that more prominence should be given to the treatment of accidents of this kind, by tracheotomy, than has been done formerly.

J.H., male in middle life, was admitted to the Western Infirmary, Glasgow, with a fractured upper arm. - Being then a house physician in the Western Infirmary, it happened to be my lot to administer chloroform. Violent struggling of an extreme type took place during the initial stage, accompanied by such voluntary apncea as to be alarming. The chloroform mask was removed till breathing became freer, though it still continued laboured. As the patient was " coming out" the inhalation was proceeded with. The pupils became somewhat contracted, and breathing regular though still embarrassed.

Suddenly stoppage of the respiration took place. The pupils remained as before and did not dilate at that stage, showing that tonic contraction was still present.

Artificial respiration did not answer, and air neither entered nor left the chest till death had undoubtedly taken place. Had tracheotomy been performed when it was manifest that artificial respiration was useless instead of persisting with it, in all probability a totally different result would have been secured. This case was that of a middleaged, very robust man, apparently in perfect health. His heart was not sound, and at the post-mortem examination old pericarditis with adhesions and hypertrophy of the heart, with mitral disease, were found. The heart condition might account for the comparative suddenness of the death.

The efforts to breathe, which were noted in this, as in the former cases, with an obstructed windpipe, would put extra strain on the circulatory system within the chest. The positive or negative Valsalva's experiment gives rise to most alarming symptoms and signs, as any one who has tried the experiment knows. So in this case the extra strain thrown on a damaged heart would cause death to be more rapid than it would otherwise have been.

In the cases in which tracheotomy was performed no obvious harm accrued, and I believe the procedure should be used in desperate cases of this sort without hesitation.

\section{CASE OF SNAKE BITE TREATED BY CAL- METTE'S ANTIVENENE SERUM : RECOVERY.}

By Surgeon-Major S. J. RENNIE, A.M.S., Meerut, India.

THE following is of interest in being one of the first cases of snake bite treated in India with Professor Calmette's antivenene serum.

About 6.30 P.M., on September 21st, a Hindu boy, aged II, son of a groom, was drawing water from a well, and in returning accidentally stepped on a snake, which bit him on the right foot, the foot being bare at the time. Two men were with him who both saw the snake, but were unable to kill it before it disappeared in the grass. They promptly bound the end of a pugaree tightly round the boy's leg, and, picking him up, ran with him to my quarters. Not more than three minutes elapsed from the time he was bitten until I saw him. The typical imprint of a snake bite, with its two deep fang punctures and the crescentic row of small teeth marks between, was clearly seen on the inner side of the right foot. It being "the hour at which men most do congregate at the club," no fewer than five medical officers were on the spot in a few moments. I at once injected $8 \mathrm{c.cm}$. of Calmette's antivenene serum into the subcutaneous cellular tissue of his abdomen. At the same time Surgeon-Major Birt, A.M.S., treated the wounds and their immediate neighbourhood with a hypodermic solution of permanganate of potash, after which they were carefully washed and dressed. The case was then placed under observation and seen from time to time during the evening, but the patient never had a bad symptom, and is now running about as well as ever he was.

REMARKS. - There is no doubt one weak point in the above case-namely, that the snake was not killed, and that, therefore, there might be an element of doubt as to the nature of its species. The reptile, however, was clearly seen by both men who were with the boy, who gave an accurate description of it, and recognised it as a krait (bungarus cæruleus), that most deadly and dangerous Indian snake. The characteristics also of the wounds were clearly those of a bite from a snake with fangs. My own personal observation led me at once unhesitatingly to conclude that the injuries were caused by a poisonous snake, and in this I was borne out by the unanimous opinion of the five medical officers by whom the case was seen, several of them of long and varied experience in India. Taking all these points into consideration there can, I think, be little doubt that the boy was bitten, and bitten savagely and deeply, by a krait, a bite from which under ordinary circumstances is necessarily fatal.

\section{MEMORANDA: \\ MEDICAL, SURGICAL, OBSTETRICAL, THERA- PEUTICAL, PATHOLOGICAL, ETo.}

\section{MALARIA AT ADEN.}

WiTH reference to the memorandum of Surgeon-Captain Jones, I.M.S., in the British Medical JournaL of October 3Ist, giving a table which shows the extraordinary and progressive increase in the number of cases of malarial fevers amongst the civil population of Aden since the year 1885, I wish to point out that a corresponding increase took place at the same time in the number of admissions for these diseases amongst the European troops quartered there. ${ }^{1}$

I was in charge of the Station Hospital, Aden, from October, 1892 , to October, 1894 , and from previous reports and inquiries $I$ found the prevalence of malaria attributed to 4 causes :

x. Increased rainfall.

2. Disturbance of ground in making forts at Steamer Point.

3. Dredging of the harbour.

4. The establishment of salt works on the isthmus.

I. As regards rainfall on reference to Surgeon-Captain Jones's table it will be seen that in 1885 the fall was 12 inches, in 1886 it was 3 inches, while in 1890 it was 12 inches and in 18914 inches. Therefore the years $1890-91$ were as regards rainfall counterparts of the years $1885-86$, but the last-named years were not characterised by any increase in the amount of malarial fever, and this was the case also as regards European troops. ${ }^{2}$ Why, therefore, should a certain rainfall cause malaria in 1890-91, when the same rainfall did not do so in $1885-86$ ?

2. The disturbance of soil took place at Steamer Point. The station of Aden consists of three separate "positions":

(a) Steamer Point, situated on the harbour.

(b) The Isthmus Position, separated from Steamer Point by a large plain and by a range of precipitous hills, which also separate it from the harbour.

(c) The Crater Position, separated from both Steamer Point and the sthmus by hills.

Now, of these three positions, the isthmus was by far the most unhealthy, and had to be abandoned by troops in 1892 on this account; the latter came next as regards unhealthiness; and Steamer Point, where all the fortifications were made, was the least unhealthy.

$$
1 \text { Army Medical Reports, 1892, p. } 143 .
$$

